\title{
PENGARUH KUALITAS PRODUK, PROMOSI DAN HARGA TERHADAP KEPUTUSAN PEMBELIAN MOBIL BEKAS MEREK AVANZA DI KOTA PADANG
}

\author{
Syarfri Wandi, Heryanto Abaharis \\ Sekolah Tinggi Ilmu Ekonomi “KBP” Padang \\ Swandi.Armada@gmail.com
}

\begin{abstract}
The purpose of this research is to find out and analyze the influence of the quality of products, promotion and price against the used car purchase decisions brands Avanzain Padang city.The sampling technique used was purposive sampling, while the number of samples that are used for the analysis is 100 people.Data analysis techniques were used to test the hypothesis is a multiple linear regression.In this study there are three variables, namely product quality, promotion and price. Variables have a significant influence of product purchases a used car brand of the Avanza in the city of Padang is the quality of the product and the price. While the value of the coefficient of determination in this study found of 0.694 or equal to 69.4\%.The results showed that of the purchasing decision can be explained by the quality of products, promotions and rates of $69.4 \% 30.6 \%$, while the rest allegedly explained by other factors not examined in this study.Based on the results of the testing of multiple linear regression analysis, it was found that the variable quality of product, price and promotion of a positive effect against the used car purchase decisions brands Avanza in Padang city.This research provides practical recommendations for the management of used car sales showroom in Padang city to continue to strive to improve the quality of the product and the price in the future.This is because the quality of the products and price have a meaningful influence on the purchase of a used car brand of the Avanza in Padang city.
\end{abstract}

Keyword: Product Quality, Promotion rates and Purchasing Decisions

\section{Latar Belakang Masalah}

Saat ini, perkembangan jumlah penduduk yang cukup pesat serta beragamnya aktivitas kerja setiap orang memungkinkan segala aktivitas tersebut harus dilakukan secara cepat. Agar orang dapat melakukan pekerjaan secara cepat, dibutuhkan sarana pendukung, seperti sarana transportasi. Transportasi merupakan alat yang berguna untuk memindahkan barang atau orang dalam kuantitas tertentu, ke suatu tempat tertentu, dalam jangka waktu tertentu. Salah satu sarana transportasi tersebut adalah mobil.
Diantara berbagai jenis mobil, terdapat satu jenis yang paling banyak diminati konsumen, yakni kendaraan serba guna (Multi Purpose Vehicle/MPV). Oleh karena itu, saat jenis MPV dari berbagai merek membanjiri pasar mobil nasional diantaranya Toyota (Innova dan Avanza), Honda (Odyssey dan Stream), Suzuki (APV), Daihatsu (Xenia), Isuzu (Phanter), Chevrolet Zafira, Mitsubishi Chariot, Nissan Grand Livina dan lain sebagainya. Kendaraan dengan konsep MPV paling digemari oleh masyarakat Indonesia, hal ini tercermin dari penjualan 
kendaraan jenis ini yang menguasai pangsa pasar terbesar di pasar mobil nasional.

Untuk lebih meningkatkan penjualan mobil, maka pihak perusahaan perlu memperhatikan strategi bauran pemasaran dimana bauran pemasaran terdiri dari : produk, harga, promosi dan tempat. Keempat faktor tersebut sangat berpengaruh terhadap keputusan pembelian mobil bekas yang ditawarkan oleh perusahaan di Kota Padang. Keberhasilan pemasaran akan semakin meningkat apabila didukung oleh adanya suatu studi mengenai keputusan konsumen. Pada studi ini dikenal bahwa perilaku pembeli atau konsumen akan dipengaruhi oleh beberapa faktor, antara lain faktor intern dan faktor esktern, yang masing-masing dapat berperan dalam mempengaruhi perilaku konsumen .

Semakin banyaknya varian mobil yang ditawarkan oleh perusahaan-perusahaan otomotif kepada para konsumen, maka konsumen akan lebih selektif dalam menyeleksi mobil yang ditawarkan oleh perusahaan-perusahaan tersebut, supaya produk yang dibelinya sesuai dengan kebutuhannya. Konsumen lebih leluasa serta banyak menemukan alternatif pilihan mobil yang akan dibeli seperti berdasarkan dari merk/type, jenis/model, tahun pembuatan, isi silinder, beli baru atau bekas. Pada penelitian ini yang dimaksudkan dengan mobil bekas adalah mobil yang dikalangan masyarakat disebut dengan mobil second.

Dalam memilih mobil second konsumen tidak akan kebingungan dalam mencari, karena informasi dapat diperoleh dari iklan pada media cetak, via internet, showroom, bursa mobil. Berdasarkan dari sisi iklan baik via media cetak serta internet ada beberapa kendala contohnya jarak dan waktu guna melihat kondisi phisik mobil dan juga komunikasi antara penjual dan pembeli. Akan tetapi jika calon pembeli melakukan search di bursa mobil, konsumen pun akan langsung bisa lihat bermacam merk/type, jenis/model, tahun pembuatan, harga dan yang pasti kondisi fisik serta efisien waktu. Bursa mobil sekarang ini banyak kita jumpai di kota Padang.

Perkembangan penjualan mobil bekas di kota Padang mengalami penurunan penulis sudah mengamati di tiga showroom penjualan mobil di kota Padang, yaitu showroom Singgalang Motor di jalan Muhammad Hatta Tabing Padang, showroom Ragasa Motor di jalan Dr. Sutomo No. 48 Padang, dan showroom Makna Motor di jalan AR Hakim No. 63 Padang, menjelaskan terjadinya penurunan penjualan mobil bekas di ketiga showroom.

Berdasarkan data yang diperoleh dapat dilihat perkembangan penjualan mobil bekas di kota Padang periode 2012 sampai dengan 2016 dari tiga showroom yang diamati, serta di beberapa showroom lain dan pada jual perorangan. Pada tahun 2012 sampai dengan 2015 penjualan mobil bekas Avanza terus meningkat, sedangkan pada tahun 2015 dan 2016 penjulan mobil bekas mengalami penurunan yang signifikan. Hal ini memberikan indikasi bahwa keputusan pembelian mobil bekas di kota Padang menjadi hal yang menarik untuk diteliti.

Besarnya peluang dan juga tantangan bagi para pemasar dalam persaingan untuk merebut konsumen mobil bekas di kota Padang, membuat 
para pemasar harus lebih cerdas dalam menyusun strateginya yaitu dengan mengetahui pertimbangan-pertimbang an konsumen dalam melakukan pembelian. Sehingga dapat membantu para pemasar untuk menentukan segmen pasar dan juga strategi. Oleh karena itu, para pemasar dalam mencapai tujuannya tersebut harus mengetahui terlebih dahulu apa yang diinginkan dan yang dibutuhkan oleh konsumen. Dalam hal ini dapat dilakukan dengan cara mempelajari bagaimana kualitas produk, promosi dan harga pada mobil bekas merek Avanza di Kota Padang.

\section{Rumusan Masalah}

1. Bagaimana pengaruh kualitas produk terhadap keputusan pembelian mobil bekas merek Avanza di Kota Padang?

2. Bagaimana pengaruh promosi terhadap keputusan pembelian mobil bekas merek Avanza di Kota Padang?

3. Bagaimana pengaruh harga terhadap keputusan pembelian mobil bekas merek Avanza di Kota Padang?

\section{Tujuan Penelitian}

1. Untuk menganalisis pengaruh kualitas produk terhadap keputusan pembelian mobil bekas merek Avanza di Kota Padang.

2. Untuk menganalisis pengaruh promosi terhadap keputusan pembelian mobil bekas merek Avanza di Kota Padang.

3. Untuk menganalisis pengaruh harga terhadap keputusan pembelian mobil bekas merek Avanza di Kota Padang.

\section{LANDASAN TEORI \\ Keputusan Pembelian}

\section{Pengertian Keputusan Pembelian}

Keputusan pembelian adalah tahap selanjutnya setelah adanya niat atau keinginan membeli, namun keputusan pembelian adalah tidak sama dengan pembelian yang sebenarnya (Morissan, 2010).

Kotler dan Keller (2009) mengatakan dalam tahap evaluasi konsumen memben-tuk preferensi antar merek dalam kumpulan pilihan. Konsumen mungkin juga membentuk maksud untuk membeli merek yang paling disukai.

\section{Kualitas Produk}

\section{Pengertian Kualitas Produk}

Menurut Kotler dan Keller (2009) produk adalah segala sesuatu yang dapat ditawarkan kepada pasar untuk memuaskan suatu keinginan atau kebutuhan, termasuk barang fisik, jasa, pengalaman, acara, orang, tempat, properti, organisasi, informasi dan ide. Selanjutnya Tjiptono (2008) mengatakan produk adalah segala sesuatu yang dapat ditawarkan produsen untuk diperhatikan, diminta, dicari, dibeli, digunakan atau dikonsumsi

Lupiyoadi dan Hamdani (2009) menyatakan bahwa produk merupakan keseluruhan konsep obyek atau proses yang memberikan sejumlah nilai manfaat kepada konsumen. Yang perlu diperhatikan dalam produk adalah konsumen tidak hanya membeli fisik dari produk tetapi membeli benefit dan value dari produk tersebut.

\section{Promosi \\ Pengertian Promosi}

Promosi merupakan salah satu variable dalam bauran pemasaran yang sangat penting dilaksanakan oleh 
perusahaan dalam memasarkan produk jasa. Kegiatan promosi bukan saja berfungsi sebagai alat komunikasi antara perusahaan dengan konsumen, melainkan juga sebagai alat untuk mempengaruhi keputusan konsumen sesuai dengan keinginan dan kebutuhannya (Rambat dan Ahamad, 2008).

Kotler dan Armstrong (2008) menyatakan bahwa promosi berarti aktivitas yang menyampaikan manfaat dan membujuk pelanggan membelinya. Sedangkan Kotler dan Keller (2009), menyatakan bahwa komunikasi pemasaran adalah sarana dimana perusahaan berusaha menginformasikan, membujuk dan mengingatkan konsumen secara langsung maupun tidak langsung tentang produk dan merek yang dijual. Intinya komunikasi pemasaran merepresentasikan suara perusahaan dan mereknya serta merupakan sarana dimana perusahaan dapat membuat dialog dan membangun hubungan dengan konsumen.

\section{Harga}

\section{Pengertian Harga}

Harga adalah sejumlah uang yang ditagihkan atas suatu produk atau jasa, atau jumlah dari nilai yang ditukarkan para pelanggan untuk memperoleh manfaat dari memiliki atau menggunakan suatu produk atau jasa (Kotler dan Armstrong, 2008). Sedangkan menurut Ali (2013), harga merupakan segala bentuk biaya moneter yang dikorbankan oleh konsumen untuk memperoleh, memiliki, memanfaatkan sejumlah kombinasi dari barang beserta pelayanan dari suatu produk.

\section{Hipotesis}

Hipotesis 1 Diduga kualitas produk berpengaruh positif dan signifikan terhadap keputusan pembelian mobil bekas merek Avanza di Kota Padang.

Hipotesis 2 Diduga promosi berpengaruh positif dan signifikan terhadap keputusan pembelian mobil bekas merek Avanza di Kota Padang.

Hipotesis 3 Diduga harga berpengaruh positif dan signifikan terhadap keputusan pembelian mobil bekas merek Avanza di Kota Padang.

\section{METODE PENELITIAN \\ Populasi dan Sampel}

Melalui perhitungan dengan menggunakan rumus slovin diatas maka jumlah responden sebagai sampel dalam penelitian ini adalah sebanyak 100 orang konsumen yang telah membeli mobil bekas merek Avanza di Kota Padang dan teknik pengambilan sampel yang di gunakan dalam penelitian ini dengan menggunakan cara purposive sampling, yaitu dalam mengambil sampel dasar berdasarkan kriteria tertentu.

\section{Teknik Analisis Data}

\section{Analisis Regresi Linier Sederhana}

Uji regresi linear sederhana merupakan teknik statistik yang digunakan untuk menguji pengaruh variabel bebas terhadap variabel terikat (Sekaran, 2006:299). PPersamaan regresi linier berganda adalah:

$Y=\alpha+\beta_{1} X_{1}+\beta_{2} X_{2}+\beta_{3} X_{3}$

Di mana:

$\mathrm{Y} \quad=$ Keputusan Pembelian

$\alpha \quad=$ Konstanta 
$\beta=$ Koefisien Regresi

$\mathrm{X}_{1} \quad=$ Kualitas Produk

$\mathrm{X}_{2}=$ Promosi

$\mathrm{X}_{3}=$ Harga

\section{Pengujian Hipotesis}

\section{Uji T-Statistik}

Uji t dilakukan untuk menguji apakah secara terpisah variabel independen mampu menjelaskan variabel dependen secara baik. Kriteria pengujian:

1) Jika t hitung > t tabel, maka $\mathrm{H}_{0}$ ditolak dan $\mathrm{H}_{1}$ diterima.

2) Jika t hitung < t tabel, maka $\mathrm{H}_{0}$ diterima dan $\mathrm{H}_{1}$ ditolak.

3) Tingkat kepercayaan $\alpha$ untuk pengujian hipotesis adalah $95 \%$ atau $\alpha=0,05$

\section{HASIL PENELITIAN DAN \\ PEMBAHASAN}

\section{Hasil Analisis Regresi Berganda}

Hasil analisis regresi linier berganda dapat diringkas pada Tabel 4.16 berikut ini:

\section{Tabel 4.16}

Ringkasan Hasil Analisis Regresi Linier Berganda

\begin{tabular}{|l|c|c|c|}
\hline $\begin{array}{c}\text { Konstanta dan } \\
\text { Variabel } \\
\text { Bebas }\end{array}$ & $\begin{array}{c}\text { Koefisie } \\
\mathrm{n} \\
\text { Regresi }\end{array}$ & $\begin{array}{c}\text { Signifik } \\
\text { an }\end{array}$ & Keterangan \\
\hline Konstanta (a) & -0.184 & 0.515 & - \\
\hline $\begin{array}{l}\text { Kualitas } \\
\text { Produk (X1) }\end{array}$ & 0.582 & 0.000 & H1 Signifikan \\
\hline Promosi (X2) & 0.023 & 0.863 & $\begin{array}{l}\text { H2 Signifikan } \\
\text { Sidak }\end{array}$ \\
\hline Harga (X3) & 0.404 & 0.002 & H3 Signifikan \\
\hline
\end{tabular}

Sumber: Olahan Data SPSS, 2017.

Berdasarkan hasil analisis regresi linier berganda yang disajikan pada tabel diatas, berikut ini dapat dikemukakan persamaan regresi linier berganda:

$$
Y=-0,184+0,582 X_{1}+0,023 X_{2}+
$$

Koefisisen regresi masingmasing variabel penelitian dapat diartikan sebagai berikut:

1. Nilai konstanta sebesar $-0,184$ berarti tanpa adanya pengaruh dari variabel bebas maka nilai variabel terikat hanya sebesar $-0,184$. Hal ini berarti bahwa apabila variabel bebas nilainya konstan (kualitas produk, promosi dan harga), maka nilai variabel keputusan pembelian hanya sebesar -0,184.

2. Besaran koefisien regresi variabel kualitas produk bernilai positif bermakna jika variabel kualitas produk mengalami kenaikan maka keputusan pembelian akan mengalami peningkatan. Koefisien bernilai positif artinya terjadi hubungan positif antara kualitas produk dengan keputusan pembelian, semakin baik kualitas produk maka keputusan pembelian akan semakin tinggi. Besaran koefisien regresi variabel kualitas produk adalah 0,582 satuan. Hal ini bermakna bahwa jika terjadi peningkatan kualitas produk sebesar satu satuan dengan asumsi variabel promosi dan harga tetap, maka akan meningkatkan keputusan pembelian sebesar 0,582 satuan.

3. Besaran koefisien regresi variabel promosi bernilai positif bermakna jika variabel promosi mengalami kenaikan maka keputusan pembelian akan mengalami peningkatan. Koefisien bernilai positif artinya terjadi hubungan positif antara promosi dengan keputusan pembelian, semakin baik promosi maka keputusan pembelian akan semakin tinggi. Besaran koefisien regresi variabel promosi adalah 0,023 satuan. Hal 
ini bermakna bahwa jika terjadi peningkatan promosi sebesar satu satuan dengan asumsi variabel kualitas produk dan harga tetap, maka akan meningkatkan keputusan pembelian sebesar 0,023 satuan.

4. Besaran koefisien regresi variabel harga bernilai positif bermakna jika variabel harga mengalami kenaikan maka keputusan pembelian akan mengalami peningkatan. Koefisien bernilai positif artinya terjadi hubungan positif antara harga dengan keputusan pembelian, semakin pantas harga yang ditawarkan maka keputusan pembelian akan semakin tinggi. Besaran koefisien regresi variabel harga adalah 0,404 satuan. Hal ini bermakna bahwa jika terjadi peningkatan harga sebesar satu satuan dengan asumsi variabel kualitas produk dan promosi tetap, maka akan meningkatkan keputusan pembelian sebesar 0,404 satuan.

\section{Pengujian Hipotesis}

\section{Uji t Statistik}

Untuk melakukan uji hipotesis secara parsial, dapat dilihat dari ringkasan hasil analisis uji $\mathrm{t}$ statistik yang disajikan pada Tabel 4.17sebagai berikut:

Tabel 4.17

Hasil Uji t Statistik

\begin{tabular}{|l|c|c|l|}
\hline $\begin{array}{l}\text { Konstanta dan } \\
\text { Variabel Bebas }\end{array}$ & Alpha & $\begin{array}{c}\text { Signifi } \\
\text { kan }\end{array}$ & Keterangan \\
\hline $\begin{array}{l}\text { Kualitas } \\
\text { Produk (X1) }\end{array}$ & 0.05 & 0.000 & H1 Signifikan \\
\hline Promosi (X2) & 0.05 & 0.863 & $\begin{array}{l}\text { H2 Tidak } \\
\text { Signifikan }\end{array}$ \\
\hline Harga (X3) & 0.05 & 0.002 & H3 Signifikan \\
\hline
\end{tabular}

Sumber: Olahan Data SPSS, 2017.
Berdasarkan hasil pengolahan data pada Tabel 4.17 terlihat bahwa variabel kualitas produk memiliki nilai signifikansi sebesar 0,000 tahapan pengujian dilakukan dengan menggunakan tingkat kesalahan sebesar $5 \%(0,05)$, dengan demikian terlihat bahwa nilai signifikansi 0,000 lebih kecil dari alpha 0,05, maka keputusannya adalah Ho di tolak dan Ha diterima. Jadi dapat disimpulkan bahwa kualitas produk berpengaruh signifikan terhadap keputusan pembelian mobil bekas merek Avanza di Kota Padang.

Hipotesis kedua menunjukkan bahwa variabel promosi memiliki nilai signifikansi sebesar 0,863 tahapan pengujian dilakukan dengan menggunakan tingkat kesalahan sebesar $5 \%(0,05)$, dengan demikian terlihat bahwa nilai signifikansi 0,863 lebih besar dari alpha 0,05, maka keputusannya adalah Ho di terima dan Ha ditolak. Jadi dapat disimpulkan bahwa promosi tidak berpengaruh terhadap keputusan pembelian mobil bekas merek Avanza di Kota Padang.

Hipotesis ketiga menunjukkan bahwa variabel harga memiliki nilai signifikansi sebesar 0,000 tahapan pengujian dilakukan dengan menggunakan tingkat kesalahan sebesar $5 \%(0,05)$, dengan demikian terlihat bahwa nilai signifikansi 0,000 lebih kecil dari alpha 0,05, maka keputusannya adalah Ho di tolak dan Ha diterima. Jadi dapat disimpulkan bahwa harga berpengaruh signifikan terhadap keputusan pembelian mobil bekas merek Avanza di Kota Padang.

\section{Uji Koefisien Determinasi}

Dari proses pengujian koefisien determinasi yang telah dilakukan 
diperoleh ringkasan hasil seperti yang terlihat pada Tabel 4.19 berikut ini:

\section{Tabel 4.19}

Hasil Pengujian Koefisien Determinasi

Model Summary ${ }^{b}$

\begin{tabular}{|c|c|c|c|c|c|}
\hline $\begin{array}{l}\text { Mod } \\
\text { el }\end{array}$ & $\mathrm{R}$ & \begin{tabular}{c|}
$\mathrm{R}$ \\
Square
\end{tabular} & $\begin{array}{l}\text { Adjusted R } \\
\text { Square }\end{array}$ & $\begin{array}{l}\text { Std. Error of } \\
\text { the Estimate }\end{array}$ & Durbin-Watson \\
\hline 1 & $.839^{\mathrm{a}}$ & .703 & .694 & .46526 & 1.959 \\
\hline \multicolumn{6}{|c|}{$\begin{array}{l}\text { a. Predictors: (Constant), Harga, Kualitas Produk, } \\
\text { Promosi }\end{array}$} \\
\hline \multicolumn{6}{|c|}{ b. Dependent Variable: Keputusan Pembelian } \\
\hline \multicolumn{6}{|c|}{ Olahan Data Primer 2017.} \\
\hline
\end{tabular}

Dari hasil olahan data yang dapat dilihat pada Tabel 4.19, diketahui bahwa dari pengujian Koefisien Determinasi terlihat nilai koefisen determinasi adalah sebesar 0,694 atau sama dengan 69,4\%. Hasil tersebut memperlihatkan bahwa dari keputusan pembelian yang dapat dijelaskan oleh kualitas produk, promosi dan harga sebesar 69,4\%, sedangkan sisanya $30,6 \%$ diduga dijelaskan oleh faktorfaktor lain yang tidak diteliti dalam penelitian ini. Menurut Kotler dan Keller (2009) faktor utama perilaku pembelian terdiri atas: Faktor budaya, sub budaya, kelas sosial, keluarga, peran dan status, pribadi, usia dan psikologis, yang merupakan hal sangat penting dalam perilaku pembelian. Namun dalam penelitian ini hanya menggunakan variabel kualitas produk, promosi dan harga. yang termasuk kedalam bauran pemasaran..

\section{Pembahasan}

Pengaruh Kualitas Produk Terhadap Keputusan Pembelian

Berdasarkan hasil pengolahan data terlihat bahwa variabel kualitas produk memiliki nilai signifikansi sebesar 0,000 tahapan pengujian dilakukan dengan menggunakan tingkat kesalahan sebesar 5\% $(0,05)$, dengan demikian terlihat bahwa nilai signifikansi 0,000 lebih kecil dari alpha 0,05, maka keputusannya adalah Ho di tolak dan Ha diterima. Jadi dapat disimpulkan bahwa kualitas produk berpengaruh positif dan signifikan terhadap keputusan pembelian mobil bekas merek Avanza di Kota Padang.

Keputusan pembelian menurut Schiffman dan Kanuk (2008), dapat diartikan sebagai pemilihan dari dua atau lebih alternatif pilihan keputusan pembelian. Artinya bahwa seseorang sebelum melakukan pembelian tersedia beberapa alternatif pilihan, sehingga dia harus memilih salah satu diantaranya. Menurut Kotler dan Keller (2009) keputusan pembelian dipengaruhi oleh rangsangan pemasaran yang terdiri dari produk.

Menurut Kotler dan Keller (2009) produk adalah segala sesuatu yang dapat ditawarkan kepada pasar untuk memuaskan suatu keinginan atau kebutuhan, termasuk barang fisik, jasa, pengalaman, acara, orang, tempat, properti, organisasi, informasi dan ide. Selanjutnya Tjiptono (2008) mengatakan produk adalah segala sesuatu yang dapat ditawarkan produsen untuk diperhatikan, diminta, dicari, dibeli, digunakan atau dikonsumsi pasar sebagai pemenuhan kebutuhan atau keinginan pasar yang bersangkutan.

Hasil penelitian ini sejalan dengan hasil penelitian terdahulu yang dilakukan oleh Prisca Andini dan Susilo Toto Rahardjo (2012), dengan judul Analisis Faktor-faktor yang Mempengaruhi Keputusan Pembelian Mobil Hyundai i20 (Studi Kasus Pada Konsumen Mobil Hyundai i20 di Semarang). Hasil analisis regresi menunjukkan bahwa variabel kualitas, harga dan promosi memberikan pengaruh positif dan signifikan 
terhadap keputusan pembelian konsumen.

Penelitian yang dilakukan oleh Hendra Noky Andrianto, dan Idris (2013) dengan judul penelitian Pengaruh Kualitas Produk, Citra Merek, Harga dan Promosi terhadap Keputusan Pembelian Mobil Jenis MPV merek Toyota Kijang Innova di Semarang. Hasil penelitian menunjukkan bahwa Kualitas produk berpengaruh positif dan signifikan terhadap keputusan pembelian. Citra merek berpengaruh positif dan signifikan terhadap keputusan pembelian. Harga berpengaruh positif dan signifikan terhadap keputusan pembelian. Promosi berpengaruh positif dan signifikan terhadap keputusan pembelian.

Penelitian yang dilakukan oleh Tri Wibowo dan Sri Purwantini (2012) dengan judul penelitian Analisis Pengaruh Kualitas Produk, Harga dan Promosi terhadap Keputusan Pembelian Mobil Toyota (Studi Kasus pada PT.Nasmoco Gombel Semarang). Hasil penelitian menunjukkan bahwa ada pengaruh positif dan signifikan antara kualitas produk dengan keputusan pembelian. Harga mempunyai pengaruh positif dan signifikan terhadap keputusan pembelian. Ada pengaruh positif dan signifikan antara promosi dengan keputusan pembelian.

Penelitian yang dilakukan oleh Tri Wibowo dan Sri Purwantini (2012) dengan judul penelitian Analisis Pengaruh Kualitas Produk, Harga dan Promosi terhadap Keputusan Pembelian Mobil Toyota (Studi Kasus pada PT.Nasmoco Gombel Semarang). Hasil penelitian menunjukkan bahwa ada pengaruh positif dan signifikan antara kualitas produk dengan keputusan pembelian. Harga mempunyai pengaruh positif dan signifikan terhadap keputusan pembelian. Ada pengaruh positif dan signifikan antara promosi dengan keputusan pembelian.

\section{Pengaruh Promosi Terhadap Keputusan Pembelian}

Berdasarkan hasil pengolahan data terlihat bahwa variabel promosi memiliki nilai signifikansi sebesar 0,863 tahapan pengujian dilakukan dengan menggunakan tingkat kesalahan sebesar $5 \%(0,05)$, dengan demikian terlihat bahwa nilai signifikansi 0,863 lebih besar dari alpha 0,05, maka keputusannya adalah Ho di terima dan Ha ditolak. Jadi dapat disimpulkan bahwa promosi tidak berpengaruh signifikan terhadap keputusan pembelian mobil bekas merek Avanza di Kota Padang.

Penelitian ini tidak sejalan dengan penelitian yang dilakukan oleh Tri Wibowo dan Sri Purwantini (2012) dengan judul penelitian Analisis Pengaruh Kualitas Produk, Harga dan Promosi terhadap Keputusan Pembelian Mobil Toyota (Studi Kasus pada PT.Nasmoco Gombel Semarang). Hasil penelitian menunjukkan bahwa ada pengaruh positif dan signifikan antara kualitas produk dengan keputusan pembelian. Harga mempunyai pengaruh positif dan signifikan terhadap keputusan pembelian. Ada pengaruh positif dan signifikan antara promosi dengan keputusan pembelian.

Penelitian yang dilakukan oleh Prisca Andini dan Susilo Toto Rahardjo (2012), dengan judul Analisis Faktorfaktor yang Mempengaruhi Keputusan Pembelian Mobil Hyundai i20 (Studi Kasus Pada Konsumen Mobil Hyundai i20 di Semarang). Hasil analisis regresi menunjukkan bahwa variabel kualitas, harga dan promosi memberikan 
pengaruh positif dan signifikan terhadap keputusan pembelian konsumen.

\section{Pengaruh Harga \\ Keputusan Pembelian}

Berdasarkan hasil pengolahan data terlihat bahwa variabel harga memiliki nilai signifikansi sebesar 0,002 tahapan pengujian dilakukan dengan menggunakan tingkat kesalahan sebesar 5\% (0,05), dengan demikian terlihat bahwa nilai signifikansi 0,002 lebih kecil dari alpha 0,05, maka keputusannya adalah Ho di tolak dan Ha diterima. Jadi dapat disimpulkan bahwa harga berpengaruh signifikan terhadap keputusan pembelian mobil bekas merek Avanza di Kota Padang.

Menurut Kotler dan Keller (2009) keputusan pembelian dipengaruhi oleh rangsangan pemasaran yang terdiri dari harga. Harga merupakan satu-satunya bauran pemasaran yang menghasilkan pendapatan, sedangkan unsur lainnya menimbulkan biaya. Harga juga merupakan salah satu unsur bauran pemasaran yang paling fleksibel dan dapat diubah dengan cepat.

Harga suatu produk ditentukan tidak saja berdasarkan biaya produksi namun juga factor-faktor lain, tingkat permintaan terhadap produk bersangkutan, tingkat persaingan, serta persepsi konsumen terhadap ptoduk (Morissan, 2010). Kesalahan unum lainnya termasuk penetapan harga yang terlalu berorientasi pada biaya dari pada berorientasi pada nilai bagi pelanggan, dan penetapan harga tidak memasukkan bagian lain dalam bauran pemasaran kedalam perhitungan-nya.

Dalam memutuskan strategi penentuan harga harus diperhatikan tujuan dari penentuan harga itu sendiri, antara lain: bertahan, memaksimalkan laba, memaksimalkan penjualan, gengsi, pengembalian atas investasi (Rambat dan Ahmad, 2008).

Hasil penelitian ini sejalan dengan hasil penelitian terdahulu yang dilakukan oleh Ahmad Muanas (2014) dengan judul penelitian Pengaruh Produk Harga, dan Promosi terhadap Keputusan Pembelian Mobil Buana Indomobil Trada. Hasil pengujian menunjukkan bahwa variabel produk berpengaruh signifikan terhadap keputusan pembelian mobil Suzuki pada PT. Buana Indomobil Trada Surabaya. Hasil pengujian kedua menunjukkan variabel harga berpengaruh signifikan terhadap keputusan pembelian mobil Suzuki pada PT. Buana Indomobil Trada Surabaya. Hasil pengujian selanjutnya menunjukkan bahwa variabel promosi berpengaruh signifikan terhadap pembelian mobil Suzuki pada PT. Buana Indomobil Trada Surabaya.

Penelitian yang dilakukan oleh Tri Wibowo dan Sri Purwantini (2012) dengan judul penelitian Analisis Pengaruh Kualitas Produk, Harga dan Promosi terhadap Keputusan Pembelian Mobil Toyota (Studi Kasus pada PT.Nasmoco Gombel Semarang). Hasil penelitian menunjukkan bahwa ada pengaruh positif dan signifikan antara kualitas produk dengan keputusan pembelian. Harga mempunyai pengaruh positif dan signifikan terhadap keputusan pembelian. Ada pengaruh positif dan signifikan antara promosi dengan keputusan pembelian.

\section{KESIMPULAN DAN SARAN Kesimpulan}

1. Kualitas produk berpengaruh signifikan terhadap keputusan 
pembelian mobil bekas merek Avanza di Kota Padang.

2. Promosi tidak berpengaruh signifikan terhadap keputusan pembelian mobil bekas merek Avanza di Kota Padang.

3. Harga berpengaruh signifikan terhadap keputusan pembelian mobil bekas merek Avanza di Kota Padang.

4. Dari hasil olahan data, diketahui bahwa dari pengujian Koefisien Determinasi sebesar 0,694 atau sama dengan $69,4 \%$. Hasil tersebut memperlihatkan bahwa dari keputusan pembelian yang dapat dijelaskan oleh kualitas produk, promosi dan harga sebesar $69,4 \%$, sedangkan sisanya $30,6 \%$ diduga dijelaskan oleh faktor-faktor lain yang tidak diteliti dalam penelitian ini.

5. Dari analisis regresi linier berganda, ditemukan bahwa kualitas produk, promosi dan harga berpengaruh positif terhadap keputusan pembelian mobil bekas merek Avanza di Kota Padang.

\section{Keterbatasan dan Saran Penelitian}

1. Penelitian ini hanya menganilisis kualitas produk, promosi dan harga, dan masih adanya variabel lain diluar model penelitian yang mempengaruhi terbentuknya keputusan pembelian konsumen pada mobil bekas merek Avanza di kota Padang yang tidak digunakan dalam penelitian ini. Bagi peneliti selanjutnya yang tertarik mengangkat judul yang sama dengan penelitian ini penulis menyarankan agar menambah variabel lain untuk dibuktikan dalam penelitian tersebut. Hal ini dilakukan agar hasil penelitian yang ditemukan bisa menutupi kekurangan yang terdapat dalam penelitian ini.

2. Objek penelitian ini hanyalah konsumen yang membeli mobil bekas merek Avanza, jadi disarankan bagi peneliti selanjutnya untuk dapat mengambil objek penelitian yang lain agar kajian tentang kualitas produk, promosi dan harga serta keputusan pembelian dapat dipahami secara mendalam.

3. Sulitnya bagi peneliti untuk menentukan sampel yang benar dapat mewakili seluruh populasi sehingga mempengaruhi hasil yang ditemukan didalam penelitian ini. Bagi peneliti selanjutnya disarankan untuk mampu mencoba memperbanyak jumlah responden dan lebih selektif dalam memilih calon responden, saran ini penting untuk meningkatkan mutu dan kualitas hasil penelitian.

4. Metode analisis data dalam penelitian ini menggunakan metode analisis regresi linier berganda, jadi disarankan bagi peneliti selanjutnya untuk dapat menggunakan metode analisis yang lain agar kajian tentang kualitas produk, promosi dan harga serta keputusan pembelian dapat dipahami secara mendalam.

\section{UCAPAN TERIMA KASIH}

Dalam menyelesaikan artikel ini, penulis mengucapkan terima kasih sebesar-sebesarnya kepadaBapak FebryandhieAnanda, SE, M.si selaku Ketua STIE-KBP Padang, Ibu Febsri Susanti, SEI, MM selaku Ketua Program Studi Manajemen STIE-KBP Padang, Bapak Henryanto Abaharis,SE, M.si selaku pembimbing serta Bapak 
dan Ibu Dosen beserta staf STIE-KBP yang dengan segala dedikasinya telah memberikan pengetahuan serta bimbingan kepada penulis selama mengikuti perkuliahan.

\section{DAFTAR PUSTAKA}

Agustina M. Kaeng, dkk. 2014. Bauran Promosi Pengaruhnya Terhadap Keputusan Pembelian Motor Yamaha Di Pt. Hasjrat Abadi. Jurnal Emba 1077 Vol.2 No.3 September 2014, Hal. 10771088

Andika, A., \& Susanti, F. (2018). Pengaruh Marketing Mix Terhadap Keputusan Pembelian Parfum di Azzwars Parfum Lubeg Padang. https://doi.org/10.31227/osf.io/u $\operatorname{pgc} 3$

Ali Hasan.2013. Marketing dan KasusKasus Pilihan. CAPS

Ari Wibowo. 2014. Pengaruh Kualitas Layanan, Harga Dan Lokasi Terhadap Keputusan Pembelian Di 'D'stupid Baker" Surabaya. Jurnal Ilmu \& Riset Manajemen Vol. 3 No. 12 (2014)

Dewa Bagus Nugraha Windusara dan A.A. Gd Agung Artha Kusuma. 2015. Pengaruh Bauran Promosi Terhadap Keputusan Pembelian Oppo Smartphone. E-Jurnal Manajemen Unud, Vol. 4, No. 12, 2015: 4160 - 4185 Issn : 2302-8912 4160

Eko Putro Widoyoko. 2012. Teknik Penyusunan Intrumen Penelitian. Yogyakarta: Pustaka Belajar.

Fandy Tjiptono. 2011. Manajemen \& Strategi Merek. Yogyakarta: Andi Offset.

Fira Dinan1,dkk. 2016. Analisis FaktorFaktor Yang Memengaruhi
Keputusan Pembelian Produk Kosmetik Oriflame Pada Mahasiswi Universitas Muhammadiyah Jember. Jurnal Manajemen Dan Bisnis Indonesia Vol 2. No. 1 Juni 2016

Husein Umar.2013.Metode Penelitian Untuk Skripsi dan Tesis Bisnis. PT. Raja Grafindo: Jakarta

Knapp, E Duane.2002.The Brand Mindset.Yogyakarta: Andi.

Kotler, Philip dan Armstrong. 2008. Prinsip-prinsip Pemasaran Jilid 1.Edisis 12. Erlangga: Jakarta.

Kotler, Philip dan Keller, Kevine. Lane.2009. Manajemen Pemasaran. Jilid 2. Edisi 13. Erlangga: Jakarta.

Marlius, D. (2017). Keputusan Pembelian Berdasarkan Faktor Psikologis Dan Bauran Pemasaran Pada PT. Intercom Mobilindo Padang. Jurnal Pundi. Volume 1. No. 1. Hal. 57-66.

https://doi.org/10.31575/jp.v1i1. $\underline{9}$

Marlius, D. (2016). Pengaruh Bauran Pemasaran Jasa Terhadap Minat Nasabah Dalam Menabung Pada Bank Nagari Cabang Muaralabuh.

https://doi.org/10.31227/osf.io/v dqgx

Mayliza, R. (2019). Analisis Keputusan Pembelian Ulang Axis Ditinjau Dari Bauran Pemasaran Kasus Di Kota Padang. https://doi.org/10.31219/osf.io/e 7xhy

Michael Lontoh. 2016. Analisis Pengaruh Bauran Promosi Terhadap Keputusan Pembelian Mobil Toyota Pada Pt. Hasjrat 
Abadi Manado Cabang Tendean. Jurnal Berkala Ilmiah Efisiensi Volume 16 No. 01 Tahun 2016

Morissan.2010.Periklanan: Komunikasi Pemasaran Terpadu. Jakarta: Kencana

Mowen, J.C dan Minor, M. 2002. Perilaku Konsumen. Jilid 2, Edisi Kelima. Penerbit: Erlangga, Jakarta.

Nyoman Dantes.2012.Metode Penelitian.Yogyakarta: Andi Offset

Schiffman, Leon. G dan Leslie L. Kanuk. 2008. Perilaku Konsumen. Penerbit: Indeks, Jakarta.

Rambat Lupiyoadi dan Ahmad Hamdani, A. 2009. Manajemen Pemasaran Jasa. Jakarta: Penerbit Salemba Empat.

Sekaran, Uma. 2006. Research Methods For Business, Edisi Keempat. Penerbit: Salemba Empat, Jakarta.

Sugiyono. 2013. Metode Penelitian Manajemen, Cetakan Pertama, Penerbit: Alfabeta, Bandung.

Suharsimi Arikunto. 2010. Prosedur Penelitian: Suatu Pendekatan Praktek. Edisi Revisi V. Jakarta: Rineka Cipta.

Susanti, F., \& Gunawan, A. C. (2019). Pengaruh Bauran Promosi Dan Harga Terhadap Keputusan Pembelian Produk Kosmetik Maybelline Di Kota Padang. https://doi.org/10.31227/osf.io/n pjqh 